\title{
Geotechnical Investigation of Land Movement on Roadway at KM 23, Citatah Area, West Java Province
}

\section{Achmad Subardja Djakamihardja}

\begin{abstract}
Citatah landslide was indicated at the section of $\mathrm{Km} 23$, from Bandung-Jakarta main road, West Java, Indonesia. Its dimension is approximately $200 \mathrm{~m}$ long located at the medium to steep morphology. This present activity affects the roadway, which pass through the landslide body. The detail engineering geological and geophysical investigation have been done in order to study the bahavior of soil and rock creep at Citatah landslide. Resistivity analysis shows that the unstable soil layer has resistivity between 23-25 $\Omega m$, the interlayer of clay, silt and sandstone have resistivity between 7-17 $\Omega m$, claystone between 2-7 $\Omega$ m, and andesitic rock, as a sill, is between 40-85 $\Omega \mathrm{m}$. The rock analysis observed from shallow drilling hole shows correlation with the resistivity of the rock types. The layer of claystone found at the depth of $9 \mathrm{~m}$, within bore hole 1 , is indicated the value of resistivity between 3-7 $\Omega \mathrm{m}$. Within bore hole 2, claystone found at the depth of $14 \mathrm{~m}$. These claystone layers are interpreted as sliding planes. This result of investigation could be considered for the mitigation of landslide around this area. So the proposed road is suggested to be placed on the andesitic rock which is situated in between the claystone layers belong to Batuasih formation.
\end{abstract}

Keywords: landslide, soil and rock behaviour, engineering geological and geophysical investigation, resistively, sandstone, claystone, andesitic rock

Naskah masuk: 7 Oktober 2008

Naskah diterima: 10 November 2008

Achmad Subardja Djakamihardja

Pusat Penelitian Geoteknologi LIPI

Kompleks LIPI Jl. Sangkuriang Bandung

Email: subardja@geotek.lipi.go.id

\begin{abstract}
ABSTRAK Gerakan tanah di daerah Citatah terjadi di $\mathrm{km} 23$ jalan raya dari Bandung ke Jakarta, Jawa Barat, Indonesia. Dimensi lereng yang longsor diperkirakan sepanjang 200 meter yang terletak di daerah dengan morfologi sedang sampai tinggi. Aktifitas gerakan tanah diatas memberikan dampak terhadap jalan tersebut yang melintasi badan lereng yang longsor. Penelitian geologi teknik dan geofisik dilakukan untuk mempelajari mekanisme dan karakter dari tanah dan batuan pada longsoran/rayapan diatas. Analisis tahanan jenis menunjukkan bahwa lapisan tanah yang tidak stabil mempunyai nilai antara 23-25 $\Omega \mathrm{m}$, lapisan antara batulempung berupa silt dan batupasir, mempunyai nilai tahanan jenis antara 7-17 $\Omega \mathrm{m}$, tahanan jenis batulempung antara 2-7 $\Omega \mathrm{m}$, and batuan andesit sebagai sill antara 40-85 $\Omega \mathrm{m}$. Analisis conto inti batuan yang diambil dari pemboran dangkal memperlihatkan hubungan antara nilai tahanan jenis dan jenis batuan. Lapisan batulempung pada lubang bor 1 dengan kedalaman $9 \mathrm{~m}$, memberikan indikasi nilai tahanan jenis antara 3-

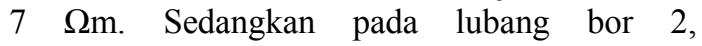
batulempung pada kedalaman $14 \mathrm{~m}$. Kedua lapisan batulempung diatas diperkirakan merupakan bidang lincir dari gerakan tanah. Hasil dari penyelidikan yang telah dilakukan dapat dijadikan pertimbangan dalam melakukan teknik mitigasi longsoran di daerah ini. Untuk itu lintasan jalan yang diusulkan disarankan untuk melintasi diatas batuan andesit yang terletak diantara batulempung diatas, yang merupakan formasi Batuasih.
\end{abstract}

Kata kunci : gerakan tanah, katakter tanah dan batuan, penyelidikan geologi teknik dan geofisik, tahanan jenis, batupasir, batulempung, batu andesit. 


\section{INTRODUCTION}

Most of Indonesian areas were covered by the youngest formation of the Quaternary deposits. Moreover, the volcanic belt passing through Sumatera and Java islands, Nusa Tenggara and Maluku archipelagos, and North Sulawesi, creates many unstable areas which may cause geological hazards including land movement. The Citatah area, in which the study was carried out, located at West Java Province, passed by road connecting Jakarta and Bandung. This area constitutes one of landslide zones in West Java. The first land movement reported in Citatah was investigated by L.J.G. van Es in 1932 (Joedo, 1975).

It is considered that the landslides occurred in this area are significantly influenced by the geological environment, climatology, hydrology, and road works coupled with land use problems created by the people who live in that area. The purpose of this study is to outline a systematic study of landslide investigations and seek an overall pattern of failures on slopes in the area under investigation. This procedure will be beneficial for gaining a better understanding of the mechanism and development of landslides in order to improve remedial measures. It will also play an important role in selecting the best alternative road location. On the other side, the investigation of geological, geotechnical, and geomorphological parameters of the body of landslide constitute an important key to formulating a suitable design for the slope.

To obtain basic data and information, field work, including a series of in site soil testing was carried out and then followed by laboratory test work. Field work also included topographical mapping, surface and sub-surface geological mapping (including structural mapping of joints), the recording of springs, public wells and ground water levels. Geophysical exploration using the resistivity method has been carried out to indicate sub-surface lithology. Two bore holes were drilled through the body of the existing landslide to obtain sub-surface geological data. Two inclinometers were installed in the boreholes to monitor the behaviour of the landslide and to determine the movement, direction and the depth of the failure plane.

\section{GENERAL VIEW OF THE AREA UNDER INVESTIGATION}

\section{Physiography}

The locality of Citatah is situated on the western side of Bandung, West Java, and is traversed by the main and busiest road connecting Jakarta to Bandung. The area is within longitudes 107 o 49' 53" and 107 o 49' 58" East and latitudes 7 o $26^{\prime} 45^{\prime \prime}$ and 7 o 27' 05" South. The area is characterized by a ridge and valley system, and located at about $640 \mathrm{~m}$ to $690 \mathrm{~m}$ above sea level.

The study area constitutes a part of the Rajamandala Mountains which consists of two types of morphology. Firstly, the limestone formation forms scarps, trending easterly and also forms some separate steep hills. The second morphology is formed by claystone, sandstone, and shale which constitute a valley in between the separate limestone hills and the limestone scarp. These rocks are identified as weak rocks which are unstable in steep slopes and are prone to down slope movement when saturated. The higher elevations are present to the south, in the form of limestone hills, whereas the valleys are the typical features of the lower elevation at the northern area. High steep slopes characterize the northern side of the limestone hills, in contrast to the gentle slopes of the southern sides (Sampurno, 1977).

In general, Indonesia has climatic variations influenced by an inter-tropical convergence pattern. It is characterized by a prolonged wet season from September to May which is followed by a dry season from May to September. The intensity and frequency of rainfall in West Java are influenced mainly by the ground elevation and the period of the tropical convergence. The rainfall records collected over a period of the last ten years indicates that the average monthly rainfall is about $150 \mathrm{~mm}$. Peak rainfall generally occurs during October to April, with a rate of between 
$200 \mathrm{~mm}$ to $300 \mathrm{~mm}$ per. This corresponds to the periods when the majority of the landslides were reported. According to Heath (1988), the Indonesian climate provides one of the most active chemical weathering environments $t$ o be found anywhere in the world. This typical climate leads to intense rock weathering processes. Average temperature is about $23^{\circ} \mathrm{C}$ with a maximum temperature of $28.5^{\circ} \mathrm{C}$ and a minimum temperature of $18^{\circ}$ Celsius. Humidity in this area ranges between $73 \%$ to $84 \%$ with peak humidity occurring during January and the minimum during September.

\section{GENERAL THEORY OF LAND MOVEMENT}

\section{Slope Stability}

The most common methods of computing analysis when studying a slope instability problem are the two dimensional limit equilibrium method of analysis which uses the method of slices for soil stability. Similar computational and empirical methods are used to assess rock stability. These can be applied to accommodate the complex geometric pattern of rock discontinuities and the variable geotechnical properties of soils, rocks, and groundwater conditions (Fellenius, 1936).

The basic assumption is that the MohrCoulomb Failure Criterion must be satisfied along the sliding surface of failure. A block of material is assumed to be a free mass. The force acting upon the mass is calculated and used to determine the moment equilibrium. Instability occurs when a slip surface develops and movements are initiated within the soil mass. According to Fellenius W (1936), calculation of the factor of safety is based on a mathematical analysis which determines the ratio between shear stress and shear strength of the slope Shear Strength is defined as follow:

Where:

$$
(\mathrm{t})=\mathrm{c}^{\prime}+\tan \left(\mathrm{s}^{\prime}-\mathrm{u}\right) \tan \theta
$$

$\mathrm{t}=$ shear strength of material, $\mathrm{kPa}$; $\mathrm{c}^{\prime}=$ cohesion, $\mathrm{kPa}$

$\mathrm{s}^{\prime}=$ normal stress acting on the sliding surface, $\mathrm{kPa}$

$\theta=$ angle of shearing resistance, (degrees)

$\mathrm{u}=$ pore water pressure, $\mathrm{kPa}$

The Mohr-Coulomb Failure Criterion shows the relationship between the shear stress (t), required to cause sliding along a discontinuity or sliding surface, to the normal stress (s), acting across it. Convention accepts that the shear strength of material acting on the surface of sliding can be defined by the Mohr-Coulomb failure criterion.

\section{RESULT AND DISCUSSION}

\section{Geological Condition}

Generally the study area is covered by colluviums mixed with gravel and rock fragments which are mainly limestone. This layer is formed as a result of the weathering of the bedrock which consists of black shale and grey sandy to silty clay (Batuasih Formation) which is mixed with the debris of limestone layers falling from the upper levels.

Physically, the bedrock consists of very fine grained elastic and firm clay. The weathering of this rock is mainly from the effects of direct sunlight. As a result, the color has changed to brown and some cracks have formed. The cracks have been filled with water resulting in the changing of physical characteristics from firm to soft clay. The process is on-going forming a colluvium layer covering the bedrock. Near the surface, the colluvium is mixed with the rock fragments form the limestone layer.

The surface geological work mainly consisted of topographical and geological mapping, lithological and mineralogical examinations, weathering, and structural mapping of the outcrop and rock excavation to record discontinuities and joint patterns. Subsurface investigations were carried out by geophysical exploration (resistivity method), and interpreting the existing boreholes data and inclino-meter records. 


\section{Surface Investigation}

Detailed geological mapping including minor structural mapping were carried out in the study area. The fresh cutting at KM23 $( \pm 12 \mathrm{~m}$ height $)$ constitutes the best outcrops for lithology and discontinuity mapping. To formulate the geometrical model for the cutting and landslide investigation, topographical mapping was carried out.

The topsoil overlying the area is a weathered rock which comes from the underlying bedrock. The soil is mixed with gravel (debris from the original rocks) such as quartz sandstone, quartz, shale, claystone, and gravels. The rock units underlying this area consists of grey to black shale and claystone which generally have been mylonitized, and fine to coarse-grained grey to black sandstone which belongs to the Batuasih Formation (Sujatmiko, 1972). These grey to black shales and claystones form intercalated layers with thin to thick layers of sandstone. The thickness of the intercalation layers is between a few millimetres to several metres up to a total thickness of about $12 \mathrm{~m}$. The bedding planes of this formation, generally shows dips of between $45^{\circ}-65^{\circ}$ and a strike of $\mathrm{N}-110^{\circ}$-E. This formation had been strongly deformed and then intruded by andesite in the form of a dyke (Kartijoso and Ma'moen, 1973)

\section{Sub-surface Investigation}

Sub-surface investigation was carried out using the existing borehole data (obtained from Bores 1, 2, and 3) and the inclinometer records (Bore 1 and 2) which were carried out by the Road Research Institute (Saroso, 1986) for a landslide study and to provide supporting data for the road relocation project. Geophysical investigations have also been carried out using resistivity methods with a series of five lines (measured points) and a depth of penetration of up to 30 meters.

\section{a. Boreholes Analysis.}

Bore log analysis was carried out to identify soil or rock types and also for measuring the ground water level. There were five boreholes drilled by the Road Research Institute (Saroso, 1986). Two holes (B-1 and B-2) were drilled through the landslide body on the lower side of the road (see Figure 1), and three holes (B-3, B-4, B-5) in the upper part of the road where cutting activities for road relocation being done. Four bores are interpreted to illustrate the sub-surface condition in this area. The log of boreholes B-1 and B-2 indicates that the top soil consists of soft brown clay mixed with sand and gravel. This overburden is under lied by grey to brown silt and fine to coarse grained sand, gravel and fragmented rock followed by hard, brittle, grey clay and sand. Underlying this material, there is soft silt and sand which is followed by soft clay and silt. All these layers overlie grey to black hard impermeable claystone. In the upper part of the road, where the cutting is proposed to a depth of $12 \mathrm{~m}$, the interbedded layer of claystone, siltstone and shale is intercalated with sandstone, and underlain by present at the existing road location.

\section{b. Inclinometer Measurements.}

A monitoring system has been designed by installing inclinometers into bore holes B1 and B2, within a zone inside the landslide body. The fixed inclinometer is used for monitoring horizontal slope movement. Besides recording the direction of the movement and possible surface sliding, the recording of the time of the horizontal movement, and the possible speed and acceleration of the landslide movement can be obtained (Saroso, 1986). A significant displacement has appeared in the surface area and the size tends to become smaller at depth. During a one month period, the reading of Inclinometer I show that the maximum deflection is about $90 \mathrm{~mm}$ to the North and 20 $\mathrm{mm}$ to the East. Inclinometer II indicates a displacement $50 \mathrm{~mm}$ to the North and $20 \mathrm{~mm}$ to the East. No displacement was shown at a depth of $21 \mathrm{~m}$ (Inclinometer I) and a depth of $17 \mathrm{~m}$ (Inclinometer II).

The possible sliding surface may be at a depth of $14 \mathrm{~m}$, below which the displacements tend $\mathrm{t}$ o decrease sharply. The groundwater level (measured soon after the landslide) was recorded 
at a depth of $7 \mathrm{~m}$ at Inclinometer $\mathrm{I}$ and $11 \mathrm{~m}$ at Inclinometer II. The graphs show a floor of $12 \mathrm{~m}$ (Inclinometer I) and $15 \mathrm{~m}$ (Inclinometer II).

\section{Geophysical Exploration}

Geophysical exploration is used to define possible soil configuration and the boundaries between different materials as well as to estimate some of the engineering properties, related to underground conditions such as the resistivities of various materials. Applied to the landslide, this study was expected to locate bedrock, on which the sliding surface usually occurred, so the type of possible failure could be estimated and
West). The geophysical interpretation is based on the differences of the compression wave velocity in the soil or rock. The apparent resistivity of a soil or rock then can be related empirically to soil type and soil moisture.

\section{Mineralogy}

The mineralogical identification of rocks was done by examining rock thin sections under the Petrological Microscope. For soils, a mineralogical identification, especially clay mineralogy, was determined by using the X-Ray Diffraction method. The small quantities of clay minerals associated with the sandstones obtained

Table 1. Soil Properties determined from the body of landslide

\begin{tabular}{|c|c|c|c|c|c|}
\hline \multirow[t]{2}{*}{ Soil Properties } & \multirow[t]{2}{*}{ Symbol } & \multicolumn{4}{|c|}{ Landslide Area } \\
\hline & & First layer & Second layer & Third layer & Fourth layer \\
\hline Description & & $\begin{array}{l}\text { Soft, yellow, } \\
\text { brown to black } \\
\text { clay and gravel }\end{array}$ & $\begin{array}{l}\text { brown to grey } \\
\text { silt, fragmented } \\
\text { rock, gravel }\end{array}$ & $\begin{array}{l}\text { hard grumish, } \\
\text { grey clay and } \\
\text { gravel }\end{array}$ & $\begin{array}{l}\text { hard, yellow to } \\
\text { brown silt clay }\end{array}$ \\
\hline Depth of Deposit & & $1.40-2.05 \mathrm{~m}$ & $3.40-3.95 \mathrm{~m}$ & $5.10-5.55 \mathrm{~m}$ & $8.30-8.60 \mathrm{~m}$ \\
\hline Mineralogy & & $\begin{array}{l}\text { Illite, smectite, } \\
\text { some kaolinite, } \\
\text { and quartz }\end{array}$ & $\begin{array}{l}\text { Illite, smectite, } \\
\text { some kaolinite, } \\
\text { and quartz }\end{array}$ & $\begin{array}{l}\text { Illite,smectite, } \\
\text { some kaolinite, } \\
\text { and quartz }\end{array}$ & $\begin{array}{l}\text { Illite, smectite, } \\
\text { some kaolinite, } \\
\text { and quartz }\end{array}$ \\
\hline \multicolumn{6}{|l|}{ Index Properties } \\
\hline Clay Content & & $31.20 \%$ & $39.40 \%$ & $35.48 \%$ & $51.06 \%$ \\
\hline Spesific Gravity & $\mathrm{G}$ & 2.81 & 2.74 & 2.64 & 2.73 \\
\hline Moisture Content & $\mathrm{W}$ & $25.28 \%$ & $19.93 \%$ & $28.04 \%$ & $27.75 \%$ \\
\hline Natural Density & $\gamma$ & $1.91 \mathrm{gram} / \mathrm{cm}^{3}$ & $2.08 \mathrm{gram} / \mathrm{cm}^{3}$ & $1.88 \mathrm{gram} / \mathrm{cm}^{3}$ & $2.05 \mathrm{gram} / \mathrm{cm}^{3}$ \\
\hline Liquidity index & $I L$ & 0.18 & 0.05 & 0.47 & 0.12 \\
\hline Liquid Limit & $w L$ & $56.00 \%$ & $57.00 \%$ & $38.38 \%$ & $41.92 \%$ \\
\hline Plasticity Index & $I p$ & 31.00 & 29.00 & 19.00 & 12.00 \\
\hline Plastic Limit & $p L$ & $25.00 \%$ & $28.00 \%$ & 19.00 & $29.00 \%$ \\
\hline Activity & $a$ & 0.94 & 0.86 & 1.21 & 1.42. \\
\hline \multicolumn{6}{|l|}{ Strength Characteristics } \\
\hline Cohesion & $\mathrm{cp}$ & $39.2 \mathrm{kPa}$ & $13.3 \mathrm{KPa}$ & $8.4 \mathrm{KPa}$ & $4.20 \mathrm{KPa}$ \\
\hline Angle of Internal Friction & $\theta p$ & $10.5^{\circ}$ & $10.0^{\circ}$ & $11.0^{\circ}$ & $13.5^{\circ}$ \\
\hline
\end{tabular}

explained. A resistivity method using sounding and dipole-dipole array methods was used in the investigation. The longest spacing of electrodes (Schlumberger) is $\mathrm{AB} / 2=100 \mathrm{~m}$ and the spacing between the measuring points is approximately 25-30 m, parallel to the road section (East to from the landslide area were found to consist of kaolinite, illite, quartz and mixed layers of illite and smectite. These contents of clay indicate that the susceptibility to volume change is classified as moderate or reversible. Identification of clay mineralogy constitutes an important key of the 
physical and chemical behaviour of the material in relation to the soil stability of an area. Special attention should be given in the case where the clay is classified as the swelling type.

\section{Geotechnical Investigation}

\section{a. The Soils Properties}

Soil sampling was concentrated in the area of land sliding. The soil properties to be determined are relevant for mass-movement and slope instability purposes which will be applied to evaluating the landslide in this area (KM23). The data are presented in the form of relation-ships of particular properties and are based on the depth of the strata, as can be seen in Table 1. This data will be plotted in the diagram of slope as presented in Figure 1. The determination of the stability factor both for the landslide using vector analysis gives information about some factors involved in the slope failure mechanism. The Swedish method presented by Fellenius (1936) has been applied to estimate the stability of the slope for the landslide and for the soil slope cutting at KM23 by determining the factor of safety (Table 2).

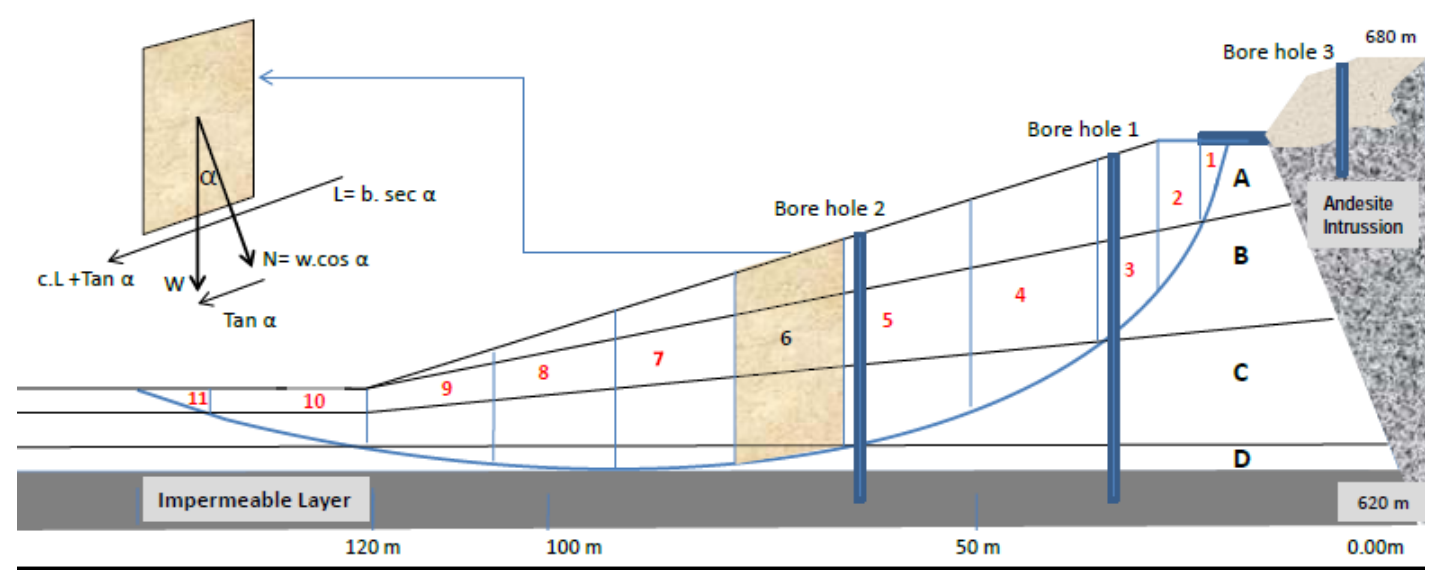

Figure 1. The body of landslide, illustrated by Swedish Method of Slices (Fellenius, 1936)

\section{b. Geological and Geotechnical Analysis}

Considering the landslide at Citatah, the effect of water on weathering profile is considered to be the main agents that triggered the landslides. The weathering process consequently plays an important role in the evolution of the landslides. In the zones where fracturing of the parent rock has been more intense, residual or colluvial soil of high permeability are often present. The landslide area is covered by layers of colluvium consisting of weathered products derived from shale and claystone and debris material. This material is usually of high permeability and easily infiltrated by water. This has a very close relationship with the development of the landslides in this area which was caused by the accumulation of water on the surface of the impermeable layer.

The investigation of soil properties (base on bore hole data) in the landslide body shows a high water content of approximately $32 \%$ which is relatively constant with depth until $14 \mathrm{~m}$, when it then decreases to be less than $15 \%$.

Laboratory tests for strength characteristics, in contrast, indicate a decrease of shear strength with the increase of the depth until the surface of the impermeable layer is encountered. It means that the water is accumulated above the 
impermeable layer, approximately $14 \mathrm{~m}$ depth. The clay content also plays an important role in slope stability. According to water sorption characteristics, the existence of swelling clay which is identified as smectite and mixed layers of smectite and illite gives the soils potential expansiveness. The Gillot Chart shows some of the soils are of medium to high potential expansiveness (Gillott, J.E. 1968).

\section{c. Stability Analysis}

A model for slope instability calculation is based on the geomorphological conditions observed at the site, and from sub-surface conditions which are obtained from bore holes. The material forming the slope is assumed to be four different behaviour layers of homogeneous soil (layers A, $\mathrm{B}, \mathrm{C}$, and D) which are underlain by an impermeable layer which acts as a slide surface. Each layer reflects a different weathering profile with different strength characteristics.

From the bore-hole data, the slip surface is estimated to be on the surface of impermeable layer, approximately $14 \mathrm{~m}$ below the road elevation. The thickness and shape of each layer is shown in Figure 1. The weathering process is more intensive in the lower part of the slope, with a total depth $14 \mathrm{~m}$ from the road elevation to the impermeable layer. The natural angle of slope before the landslide was $18^{\circ}$ measured from the elevation of road to the toe of the landslide). According to Joedo (1975), the natural slope in this area was approximately $10^{\circ}$ $15^{\circ}$ which may be classified as stable.

The increase of slope to $18^{\circ}$ at the landslide area will tend to reduce the stability of the slope. Moreover an inappropriate drainage system involving the run off from the road surface, coupled by the vibration of heavy vehicles will decrease the shear strength, and enhance the possibility of slope failure. The stability of the slope is reflected by the value of safety factor which has been calculated using the Swedish Method, in which the sliding surface is assumed to occur along a circular surface. Principally, in this method, the factor of safety is based on the comparison of the driving force value and the resisting force value. The failure mechanism must be taken into account when the stability factor is determined. The slope is classified as a stable if the value of safety factor is more than one. To make the calculation simple, the material involved in sliding is divided into eleven slices where each slice lies on the impermeable layer. Final calculation is based on the total resisting and driving forces occurring along the slip surface.

The natural density of soil $(\gamma)$ shows that the natural density of soil A is $28.10 \mathrm{~N} / \mathrm{cm}^{3}$, soil B is $27.40 \mathrm{~N} / \mathrm{cm}^{3}$, soil C is $26.40 \mathrm{~N} / \mathrm{cm}^{3}$ of and soil D is $27.30 \mathrm{~N} / \mathrm{cm} 3$. Factor of Safety then is calculated using formulae that Factor of Safety = $(\mathrm{N}$ Tan $\mathrm{f}+\mathrm{c} . \mathrm{L}+\mathrm{Tr}) / \mathrm{Td}$. The calculation results show that the value of the Factor of Safety is about 0.68. This means that the slope is unstable. Based on the formula used in this method, the small value of the Safety Factor is influenced by the value of slope angle and the value of the shear strength of the material. In general, the land movements that have occurred at the Citatah area could be classified as seasonal landslides. This is indicated by the fact that land movements usually occur during the wet season, especially after a peak of monthly rainfall. The intensive weathering process, coupled by the influence of water infiltration, constitutes a major factor in the development of landslides.

The angle of shearing resistance and soil cohesion were measured from undisturbed samples, so the influence of water content is dominant. The average water content varied between $19.9 \%$ t o $28.0 \%$ which constitutes a main factor causing the low value of shearing strength and the angle of shearing strength Stabilization of the slope, or in other words, an increase in the safety factor, would have to be done by increasing the shear strength of the material and decreasing the angle of slope. To avoid the depth of weathered soil is impossible, because of the specific bahavior of this material which is highly susceptible to weathering and its considerable thickness.

Methods of increasing the factor of safety would include:

1. Surface drainage. All run off from the road and the overlying slope must be captured and discharged remote from the landslide in 
Table 2. Stability Calculation for Landslide at Km 23, estimated by Swedish method

\begin{tabular}{|c|c|c|c|c|c|c|c|c|c|c|c|c|c|c|c|c|}
\hline \multirow{2}{*}{$\begin{array}{l}\text { S } \\
\mathbf{L} \\
\mathbf{I} \\
\mathbf{C} \\
\mathbf{E}\end{array}$} & \multirow{2}{*}{$\begin{array}{c}\alpha \\
(\operatorname{deg})\end{array}$} & \multirow{2}{*}{$\begin{array}{c}\varphi \\
(\operatorname{deg})\end{array}$} & \multicolumn{4}{|c|}{ WEIGHTFORCE } & \multirow{2}{*}{$\begin{array}{l}(\mathrm{W}) \\
\text { Total } \\
\text { Force } \\
(\mathbf{W t}) \\
(\mathbf{k N})\end{array}$} & \multirow{2}{*}{$\begin{array}{c}\text { W Sin } \alpha \\
\text { Driving } \\
\text { Force } \\
\text { (Td) } \\
\text { (kN) }\end{array}$} & \multirow{2}{*}{$\begin{array}{c}\text { W Sin } \\
\alpha \\
\text { Resisti } \\
\text { ng } \\
\text { Force } \\
\text { (Tr) } \\
(\mathrm{kN}) \\
\end{array}$} & \multirow{2}{*}{$\begin{array}{c}\text { W Cos } \alpha \\
\text { Normal } \\
\text { Force (N) } \\
(\mathrm{kN})\end{array}$} & \multirow[b]{2}{*}{$\operatorname{Tan} \varphi$} & \multirow{2}{*}{$\begin{array}{c}\mathbf{N} \operatorname{Tan} \varphi \\
(\mathrm{kN})\end{array}$} & \multirow{2}{*}{$\begin{array}{c}\mathrm{C} \\
(\mathrm{kPa})\end{array}$} & \multirow{2}{*}{$\begin{array}{l}\text { B } \\
\text { (m) }\end{array}$} & \multirow{2}{*}{$\begin{array}{c}\text { b Sec } \alpha \\
\text { L } \\
\text { (m) }\end{array}$} & \multirow{2}{*}{$\begin{array}{l}\mathrm{C} \times \mathrm{L} \\
(\mathrm{kN})\end{array}$} \\
\hline & & & $\begin{array}{c}\mathrm{A} \\
(\mathrm{kN})\end{array}$ & $\begin{array}{c}\text { B } \\
(\mathrm{kN})\end{array}$ & $\begin{array}{c}\mathrm{C} \\
(\mathrm{kN})\end{array}$ & $\begin{array}{c}\text { D } \\
(\mathrm{kN})\end{array}$ & & & & & & & & & & \\
\hline $1 \mathrm{~A}$ & 56 & 10.5 & 105.09 & * & * & * & 105.09 & 87.12 & * & 58.77 & 0.1854 & 10.90 & 39.20 & 2.20 & 3.26 & 127.85 \\
\hline $2 \mathrm{~B}$ & 51 & 10.0 & 78.68 & 8.77 & $*$ & $*$ & 87.45 & 66.40 & $*$ & 53.77 & 0.1763 & 9.48 & 13.30 & 0.80 & 0.99 & 13.14 \\
\hline $3 \mathrm{~B}$ & 45 & 10.0 & 305.73 & 175.36 & $*$ & $*$ & 481.09 & 340.18 & $*$ & 340.18 & 0.1763 & 59.97 & 13.30 & 3.20 & 3.20 & 42.56 \\
\hline $4 \mathrm{C}$ & 35 & 11.0 & 342.23 & 345.24 & 133.06 & * & 820.53 & 470.66 & * & 672.18 & 0.1944 & 130.67 & 8.40 & 4.20 & 2.94 & 24.70 \\
\hline $5 \mathrm{C}$ & 25 & 11.0 & 283.25 & 356.75 & 332.64 & * & 972.64 & 411.04 & * & 881.50 & 01944 & 171.36 & 8.40 & 4.20 & 1.96 & 16.45 \\
\hline $6 \mathrm{D}$ & 16 & 13.5 & 224.24 & 253.18 & 321.55 & 57.33 & 856.30 & 236.00 & $*$ & 823.16 & 0.2401 & 197.64 & 4.20 & 4.20 & 1.20 & 5.06 \\
\hline $7 \mathrm{D}$ & 7 & 13.5 & 157.26 & 202.76 & 306.24 & 163.80 & 830.16 & 101.20 & $*$ & 823.93 & 0.2401 & 197.83 & 4.20 & 4.00 & 0.49 & 2.06 \\
\hline $8 \mathrm{D}$ & 3 & 13.5 & 121.39 & 190.70 & 291.46 & 176.90 & 780.45 & $*$ & 40.82 & 779.36 & 0.2401 & 187.12 & 4.20 & 4.80 & 0.25 & 1.06 \\
\hline 9D & 13 & 13.5 & 42.15 & 137.00 & 217.80 & 81.90 & 478.85 & $*$ & 107.74 & 466.59 & 0.2401 & 122.03 & 4.20 & 5.00 & 1.15 & 4.85 \\
\hline $10 \mathrm{C}$ & 23 & 11.0 & $*$ & 70.14 & 54.91 & $*$ & 125.05 & $*$ & 48.86 & 115.11 & 0.1944 & 22.38 & 8.40 & 3.20 & 1.36 & 11.41 \\
\hline \multirow[t]{2}{*}{$11 \mathrm{~B}$} & 28 & 11.0 & $*$ & 16.44 & $*$ & $*$ & 16.44 & $*$ & 7.72 & 14.51 & 0.1763 & 2.56 & 13.30 & 1.50 & 0.80 & 10.61 \\
\hline & & & & & & & & 1712.59 & 205.13 & & & 1101.94 & & & & \\
\hline
\end{tabular}


an area not susceptible to sliding. All circumferential drainage ditches must be lined.

2. Sub-surface drainage, including horizontal perforated pipe drains should be reasonably successful at the slide mass has a high porosity, and shows extensive springs. An interceptor trench could be excavated round the head of the slide and filled with granular filter material and a perforated pipe which day-lights in undisturbed material.

3. The land use of the upper areas above the road for rice fields or fish farming should be avoided, because they could be a source of sub-surface water which will flow within permeable and fractured sub surface layers to the lower part of the road. Limestone quarries at the hilltop area may also create problems, as the unsuitable mining method used in the limestone excavations has left some areas which could function as water reservoirs, especially during the wet season. This water could infiltrate within the subsurface and flow into the slide area. The upslope accumulation of water constitutes a main destabilizing factor by increasing the soil water content, and increasing the unit weight of soil, and automatically decreasing the shear strength of soil. In the long term, his process will constantly disturb the moment balance and cause renewed slope failures.

\section{CONCLUSION}

Mass movement at Citatah area appears to be related to the weathering of the rock and soil type underlying the area. It was concentrated in area close to the original shale contact with colluvium layers of the Batuasih Formation. The influence of weathering on physical, chemical, and geotechnical properties of the rock, coupled by ground-water conditions, plays an important role in the development of the slope instability. The impermeable shale underlying the permeable colluvium layers may prevent the water drainage. The depth of failure related to the depth of colluvium layers which has low shear strength as a result of water content, while the sliding surface was at the impermeable shale layer. Mass movement appears to be primarily related to the condition of the material underlying the area with the failure plane within approximately $12 \mathrm{~m}$ of the ground surface.

The slope failure process may have been started by failure at the steepest part (at the toe of the slope), followed by the movement of the unstable colluvium layer at the upper part of the slope on which the road was built. It is generally believed that the mining of limestone activities and improper land uses above the road (agricultural activities), may cause the high water infiltration within the colluvium layer. Moreover, soil erosion at the toe of the slope may provide a trigger for the land movement. Some efforts should be made to prevent the possibility of failure on the road such as:

1. Relocate the road to an area which underlain by the stable foundations and avoid the area which is underlain by colluvium layers. The best area is in the above existing road which is underlain by an andesite intrusion.

2. Minimize the deleterious effects caused by inappropriate human activities in the surrounding area, such as mining and agricultural activities at the hilltop.

3. Redesign the drainage system in this area in order to minimize water infiltration, especially during the rainy season. This means a proportion of both surface and subsoil drainage

\section{REFERENCES}

Fellenius, W. 1936. Calculation of Stability of Earth Dams. Transaction of the 2nd International Congress on Large Dams. Volume 4. Balkema, Amsterdam.

Gillott, J.E. 1968. Clay in Engineering Geology. Elsevier Publishing Company, Amsterdam

Heath, W., and Saroso B.S. 1988. Natural Slope Problems Related to Road in Java, Indonesia. Proceeding of $2^{\text {nd }}$ Conference 
on Geomechanics in Tropical and residual Soil. Singapore, December 1988.

Joedo D.E. 1975. Pemeriksaan Peristiwa Gerakan Tanah Menyangkut Jalan Raya Bandung-Cianjur pada $\mathrm{km} 22.400$, Kabupaten Bandung, Jawa Barat. Archieve of Geological Survey of Indonesia, Nomor 1887.

Kartijoso S. and Ma'moen K. 1973. Geologi Daerah Gerakan Tanah pada km 22.100 - 25.00 , Jalan Padalarang-Cianjur, Jawa Barat. Archieve of Geological Survey of Indonesia, No. 1603, unpublished

Sampurno. 1977. Geologi Daerah Citatah, Padalarang, Jawa Barat dan Pengaruhnya Terhadap Lingkungan. 6nd Annual Conference of Association of Indonesian Geologists, Bandung, 5-7 December 1977.

Saroso BS. 1981, A Stability Model for Natural Slope. Internal Report, Indonesian Road Research Institutes, Publics Works Department, Indonesia.

Sujatmiko, 1972. Peta Geologi Lembar Cianjur, Jawa. Direktorat Gelogi, Departemen Pertambangan. Indonesia 